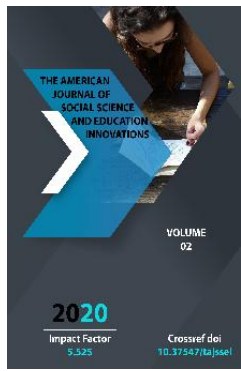

\title{
Publishing And Local Studies Activities Of The Statistical Committees In Turkestan
}

\author{
Tanzilya Ravilyevna Khamraeva \\ Head Of The Department Of World History Of Andijan State University, Andijan Region, \\ Republic Of Uzbekistan
}

Journal Website: http://usajournalshub.c om/index,php/tajssei

\section{ABSTRACT}

In this article based on a rich documentary material shows local history and publishing activities of statistical committees, the publication of articles of scientific and local history nature, the involvement of intellectuals, scientists, and travelers to the statistical service. Of particular importance for national history is the study of the history of statistical committees not only as state institutions, the order of action of which was regulated by the legislative bodies of the empire, but also as scientific and as local history centers of the regions of Turkestan. The most important of these works are a topographical description of the regions, including descriptions of individual regions of the country with their historical, geographical, administrative and economic characteristics.

\section{KEYWORDS}

Library; Statistics; Statistical Committee; Statistical Science; Census; Turkestan Region; Statistical Source; County; Review

\section{INTRODUCTION}

Several unique statistical works had been carried out in Turkestan, which served as the base for further development of statistical experience and formation of the local statistical sciences. The most important of these works were general description of
Turkestan, general survey and topographical description of regions, including description of separate areas of the country with their historic, geographical, administrative and economic characteristics. 


\section{RESULTS AND DISCUSSIONS}

After 1891 activities of committees enlarged in many aspects, committees began to collect not only review for scheduling, but also different material of particular scientific character and concerned with publishing and some degrees of enlightenment activities.

In the framework of our research, a particular attention is paid to historical-regional studies activities of the regional statistical committees. V.V. Bartold also noted this side of the matter. It was said that during the period after the conquest of Turkestan "one of the conditions of success of the scientific work was correct organization of regional study deal, which wasn't managed to reach". Bartold considered that from official publications the best place for premises of scientific articles were publication of the statistical committees. [2, p. 207-208].

The regional reviews with detailed information about "natural and production power", public facilities, irrigation system, ways of communication, population and its occupation, taxes, administrative mechanism, public health and enlightenment, public improvement, meteorological observations and etc. took a particular place. These reviews accompanied consolidated statistical tables.

About 100 reviews were published in total, including "Review of Sirdarya Region", 18861913 (Tashkent, 1887-1916), "Review of Fergana Region" 1884-1913, (New MargelanSkobelev, 1889-1916), "Review of Semirech Region” 1892-1912, (Verniy, 1893-1914), "Review of Transcaspian Regions", 1891-1914, (Ashgabad, 1893-1916). [2, p. 20] The published committee material had higher stage development of statistical date and were more detailed and objective than data having been collected by different offices of the colonial administration of the country before the organization of these committees.

In the review of the first book of collection of material for statistics of Sirdarya Region the following wasn't said in vain: "It's impossible not to be glad about appearance of this book: it's the first statistical publication in Turkestan, undertaken participation of people taken for statistical work willingly, not by on routine duty. In this, the main value of "Collection" sad experience of many years showed full insolvency of "government statistics". [3, p. 7].

Until now these material are valuable (and partially single) source studying socioeconomic and regional studies history of Turkestan from 80-90s of XIX.

Besides regional reviews, the committees also issued their works and other publications. For instance, Sirdarya committee published a volume of its works, 13 issues "collection for statistics of Sirdarya Region, as well as "address-reference book of Turkestan... with the calendar for 1910" made by I.E. Stupakov." [4, p. 306] Collection of material for the statistics of Samarkand Region is the first and single issue published by Samarkand Regional statistical committee under the editorship of M. Viskiy [16, p. 129], including statistical data for $1887-1888$ as well as several articles os Regional-Studies character (agriculture and school deal). Then, the committee published 10 issues of "Reference book of Samarkand Region” (1893-1914).

Trans Caspian Regional statistical committee was limited in this plan by publishing "Address-reference book of Transcaspian 
Regions" and "Address-reference book of Transcaspian Regions for 1915”. Fergana Regional statistical committee issued three volumes of "yearbook of Fergana Region" (Yearbook of the Fergana region (YFR), New Margelan, I-III, 1902-1904) and "Addressreference book of Fergana Region" (Skobelev, 1912).

Specified publications of the committees contained mostly publications of scientificregional studies character. It is true, not all of them stood for the former level of the scientific requirements. There were not large fundamental works among them at all. But many of have not lost their significance yet, particularly those which covered actual material. From the works, containing interesting material for historical-economic and cultural-economic description of separate populated points and terrain in Turkestan, it's fair to mention: M.S. Andreev's "Historical notes about Hodjent" (Reference book of the Samarkand region, 1896); M. Virskiy's "Essay of Yangi-Kurgan volost, Djizak uyezd, Samarkand Region on data about land-tax works" (SKSO, X, 1902); A. Vishnegirskiy's "Short list of populated places in Turkestan to January, 1888", (address-guide to Transcaspian Regions for 1915); E.T. Smirnov's "Undiscovered country, Banks of the Sirdarya, History, Husbandry and irrigation of the Kirgiz" (Collection of materials for statistics of the Samarkand region, 1895).

In the works of the committees questions related with the study of vakf and vakf documents were exposed: V.V. Blagoveshenskiy, "To the matter of vakf in Sirdarya Region" (Collection of materials for statistics of the Syrdarya region, 1891); $M$. Virskiy, "Madrassahs and mosques in
Samarkand and their vakf properties" (material for statistics of Turkestan, IV, 1886); V.L. Vyatkin, "About the vakfs in Samarkand Region" (Reference book of the Samarkand region, IX, 1907); A. Moskaltsev, "Research of vakfs in Tashkent uyzd" (Collection of materials for statistics of the Syrdarya region, IV, 1885); V.P. Nalivkin, "Position of vakf matter in Turkestan before and after its conquest" (YFR), III, 1904) and etc.

Translations of eastern manuscripts with commentaries to them were also published: V.L. Vyatkin,"Samarkand and its vicinities in the past on description of Sultan Babur Mirza", translation of "Baburnama" (Reference book of the Samarkand region, 1896); "Code of decebcy in the East" ("Adabul-salin-hin"), Collection of Mukhammed Sadik and Kashgari, Nil Likoshin translated from Turkic (IV, 1895); N.S. Likoshin- "Translation of Risola-i-tarikat" (VII, 1899); "Wisdom of Hazrat-Sultan-Arif-Hodja-Ahmad-Yassaviy", translated by N.S. Likoshin from Turkic (SMSSDO, IX, 1901), "About fortunetelling of Central Asian inhabitants", (Reference book of the Samarkand region, IX, 1907).

Publications on history and modern condition of handcrafting production of the country had significance among the ethnographic material: S. Bilkevich, "Carpet production (Turkmenistan)", “Address-guide on Transcaspian Regions for 1915"; N. Vasilyev, "Sewing workshops in Tashkent" (Collection of materials for the statistics of the Syrdarya Committee, 1892); N.I. Gabbin, "Handcrafting industry in Tashkent" (VII, 1899); and "Handcrafting industry", II, "Production of arabas" (VIII, 1900); A.A. Divayev, "Ethnographic material" (III, 1894); N.A. Kirpichnikov, "Short essay on several local 
industry in Samarkand Region" (V, 1897); U.O. Yakubovskiy,"Bindry of the local people of Samarkand" (1896) and others. Sirdarya committee (Collection of materials for statistics of the Syrdarya region, XI, 1904, XII, 1905) published two parts of extensive work of A.P. Shishlov "Sarts".

Samarkand statistical committee published mostly capital works written by V.L. Vyatkin, a well-known researcher of Turkestan, during pre-Revolutionary period. On the pages of "Reference book of Samarkand region", very important V.L. Vyatkin's works were published. For instance, translation of the manuscripts of Mir Abu Tahir, a sadr of "Samariya" of Samarkand containing the most important data for historians and archeologists on the description of Samarkand and its antiquities. "Material on the historicalgeography of Samarkand Region" (SKSO, VII, 1902) by V.L. Vyatkin had a particular significance among the material on historical topography and evaluated highly by V.V. Bartold as other "vyatkin works" (works by V.L. Vyatkin take absolutely a particular place among the works on the history of Turkestan). In our days, A.U. Yakubovskiy noted abovementioned works of V.L. Vyatkin "as valuable on the wealth of collected material". [17, p. 30].

Archeological marks of $M$. Virskiy, A. Pozdneva, F. Poryakov, V. Chertov and others, which had not lost their importance, in particular, for making archeological map of Central Asia, were also published among the committee works.

A little material was also published on economy and trade of the country, on business relations and others, rather interesting things and tests of the protocols of the statistical committee meetings.

Finally, the list of administrative points and populated places, information about private staff of civil and military institutions, educational institutions and others in the country hasn't lost their particular reference importance.

It's fair to note that committee works caused sympathetic, as a rule, more positive review not only in the local publishing but also in central scientific publications, moreover there were such great scientists as V.V. Bartold ("Notes of the Eastern Branch of the Russian archeological society", IX, pp. 297-299; XII, pp. 122-125; XIII, p. 115; XV, pp. 50-56; XVIII, pp. 181191; XXI, pp. 143-145); L.S. Berg ("News of Russian geographical society”, XI, p. 418); N.I. Veselovskiy (Statistical information on the upland Tyumen of the Zeravshan district, III, p.141) and others among the reviewers.

So, more varied contents of the statistical committee works wholly claimed and are claiming attention of researchers, first of all, working on the field of social sciences.

From the first day of its existence the committee petitioned about forming public library, institution of the rank associate member, as well as permit of publishing newspaper which would include "the works of scientists before the study of the country referring", alongside with the governmental dictations.

The proposal of the committee about publishing newspapers, its purpose and contents did not remain fur tile.

In 1870, a large print house opened, in the same year the first newspaper of the country 
"Bordereau of Turkestan" began to be published - the first official newspaper, initiated periodic publications in the country. $[15$, p. 76]

This official publication was to serve spreading information about governmental and administrative dictations in the country and assist a wide study of Turkestan and adjacent countries of the Orient. [1, p. 65-69]

In ditto, time conventionally, unofficial part of the newspapers served as the source of various information on nature, economy and history of the country. Such a famous scientists as V.V. Bartolid, I.U. Krachkovskiy, M.S. Andreyev, N.A. Arisov, V.L. Vyatkin, N.I. Veselovskiy and many others emerged with their publications here. [14, p. 76]. Already in 1870 addition to "Bordereau of Turkestan began to be published in Uzbek" ("Newspaper of Turkestan," from 1887 to 1916 - "Native newspaper of Turkestan") and its unofficial part also contained a lot of material on Regional Studies. The circulation of the newspaper and its readers were limited, publication of the 1st Uzbek newspaper itself had a particular positive importance. The material published on the pages of unofficial parts of the newspapers certain cognitive nature and certainly, assisted rapprochement of the literate part of the local population with the Russian culture.

Thereafter the addition of this newspaper was published in Uzbek and Kazak, having a purpose to bring dictations and orders of the tsarist administration of the country to the local executives. From the beginning of 1883 , these additions turned into an independent newspaper "Turkestan marginal newspaper". It became a weekly publication. Its circulation was about $500-600$ copies in total. On the pages of the newspaper, short information on the history and geography of Russia, China, India, notes on agriculture and industry of Turkestan, notes of natural sciences, geographical-astronomic references and even whole articles were published. Besides official material, extracts from the works of the classics of the Russian Literature were also published in them. Translated texts of several classic works of the Russian literature, works of the local authors as Furkat, Mukumiy and others were also published in the newspapers.

"Turkestan marginal newspaper" was not only used by Russian powers of the country as an organ, informing population about various administrative dictations and events. The readers of "Turkestan Bordereau" were basically local executives, bourgeoisie, merchants and intellectuals. These newspapers also penetrated into the local schools in the order of private subscription.

In the 80 s of XIX "Turkestan marginal newspaper" included material which introduced its readers with the lives and creative activities of A.S. Pushkin, I.S. Turgenev, L.N. Tolstoy and other greatest writers of Russia. [5, p. 215]

The democratic Russian intellectuals played an important role in development of cultural life of Turkestan. [10, p. 132] Representatives of a small local intellectuals rendered, an active help to it.

In pre-Revolutionary period other official and private publications were also issued in Turkestan. So, according to data in 1916, the followings were published in Russian in Sirdarya Region: a private newspaper "Courier of Turkestan", a weekly magazine "Agriculture in Turkestan", an illustrated 
fortnightly journal "Landowner of Turkestan". The followings were published in Uzbek: monthly journals "Dehkan" and "Islah". The newspapers "Ashgabad", "Messenger of Central Asian railways" were published in Russian, "Transcaspian native newspaper" in Turkman and Persian in Transcaspian Region. "Fergana marginal bordereau" in Russian was published in Fergana, "Voice of Turkestan" a daily newspaper in Andijan, "Semirech marginal bordereau" and from January, 1910 "Semirech agricultural slip" which was sent to all villages gratis in Semirech Region.

Articles, messages, correspondences and other material, placed in these newspapers introduced the readers not only with Russian literature and events of socio-political life in the country, Russia and other countries, but also with the achievements of sciences and technology.

After joining Turkestan to Russia an important event occurred in the field of cultural life of Central Asian nations - the typography appeared for the first time.

Before joining the country to Russia the demand for literature, in some measure, was satisfied only with manuscripts unless considering some eastern lithography, accidentally got into Turkestan from abroad. The manuscripts were multiplied by remarkable calligraphists, skillful copiers and arranged by miniaturists, public masters of the book deal [7, p. 85].

Basically, madrassahs and mosques had handwritten books in limited amount. They were not available for broad mass. The first typography opened in Tashkent in 1868.

The lithography played a greater role in deal of spreading books in Central Asia.
Books in the form of manuscript had more narrow circle of people, cost much and mainly representatives of exploiter class could afford to them.

An important consequence of joining Central Asia to Russia was activity of Russian progressive adjusted intelligence, which brought ideas of leading democratic thoughts here. As a result, political, economic and social changes began to occur, which created favorable ground for the development of progressive ideology and culture. Attracting the leading representatives of Russian sciences to the study of the country had a great importance. Many scientific expeditions set out here in the middle of XIX. Many beginner-scientists came willingly to Turkestan as teachers, doctors, agronomists etc. in order to combine official work with scientific one.

The representatives of scientific community of Russia opened a branch of all-Russian scientific institutions and societies in Central Asia and began many-sided research and cultural-educational work among the local population. Many of them devoted themselves not only to research of natural resources of Turkestan, but also to a deep study of its history, culture, language and economy.

Development of scientific research brought forth the problem of gathering printed material concerning with Turkestan and neighboring countries. Literature about the country which was little at first began to mash room after joining the country to Russia. Short reports and information about multiple expeditions, conducted after 1875 in purpose of studying and reclamation of the country, became to be published widely. The works of 
N.M. Przhevalsky, I.V. Mushketov, travel notes of P.P. Semyonov, works of N.A. Mayev about Turkestan and others were issued.

A lot of articles on particular matters of political and economic history and ethnography of Central Asia appeared in the Central periodic publications. Everyone who interested in Turkestan needed material from newspapers, journals, books. There appeared need for creation of public library in Tashkent [12, p. 11].

The first books for the library, for making perfect, which proceeded from 1867, arrived in Tashkent in 1868 with great difficulties and then there was no railway yet. The list of all donated and gained books was formed. These, several hundreds of books initiated creation and opening of Turkestan Public Library in Tashkent in May, 1870. Its organization was the first step to relief work of scientists on investigating the country.

The Public Library was the first scientific and public institution in Central Asia. But at the beginning of its activity, it developed as one of many provincial libraries of the tsarist Russia; on contents it was spent caskets, the staff did not exceed 5 people. The library was in the chancelleries of the governor-general and was managed personally by him.

The remarkable code of sources, collected in the funds of the library, was a unique "collection of compositions and articles of Turkestan referring, particularly to Central Asia and Turkestan" [8, p. 70-77]. It consisted of 594 volumes containing books and articles from newspapers and journals about preRevolutionary Turkestan.

Pre-Revolutionary existence of Turkestan Public Library had been vastly renewed for 47 years. If it had 20000 books for the first 30 years, its fund rose, more than 57800 books for the next 6-7 years, and in 1917, more than 80000 books were numbered [13, p. 38].

The activity of Turkestan Public Library noticeably brightened in 1906-1910 when the number of the readers, attendance and amount of issued books vastly increased. Somewhat it was explained that the library became available for people with little facility and students, since the guarantee for use of books for this part of readers was reduced from 1906. In 1916 books were used by 1500 readers. Thus, the number of visits was about 30000 and more than 38000 books were given out.

The first scientific and educational societies, concerning with the study of natural resources, history and economy of the local population, were organized in Turkestan with initiative of progressive adjusted Russian scientists. [9, p. 19]

In propaganda of the achievements of the Russian science and culture, in familiarization with natural wealth, past and present, life and economy of Turkestan, libraries of scientific societies formed basically from books of scientific contents, received from the members of the societies, rendered assistance. [11, p. 78]

The matter of library was repeatedly discussed in the meetings of the societies. Received books of scientific contents gratis sent on for keeping to Turkestan Public Library with the right of free use of them by society members.

Nearly simultaneously with the opening of the public library in Tashkent and in Samarkand in 1868 on order of Governor-general K.P. Kaufman, libraries opened within military 
parts and subdivisions. 11 military libraries were numbered in Tashkent and 9 in Samarkand. The base of these libraries consisted of compositions, referring to mainly military sphere and natural sciences and mathematics, had literature on other branches of knowledge as well as literary works, journals, maps, plans and others.

The initiative of organization of the libraries belonged basically to private people as well as to different enlightenment societies.

Private libraries either existed not long in Turkestan as in Russia because of lack of material support in persecution on the part of powers. All the libraries, including private ones, were under the police control. And pulling to enlightenment was so great that new and new libraries opened in the country.

It is fair to emphasize that majority of the libraries belonged to different organizations and societies as well as private people were chargeable. In 1905, a private library opened within the newspaper "Samarkand." It had more than 3000 volumes of books, also drawn central and local newspapers and journals. Each month the number of visitors increased. From April 1 to June 20, 1905, more than 1500 readers visited the library.

The opening of several provincial libraries timed for the hundredth birthday of A.S. Pushkin. So, in 1899 a town library opened in New Margelan (now Fergana). A little later, town libraries opened in Kokand and Namangan. A town library was organized in Andijan. If it had 1547 volumes of books and 11 975 people used them at the beginning of 1909 , the fund of the library rose to 4180 volumes and the number of members reached 14516 people.

\section{CONCLUSION}

Organization and development of the libraries in Turkestan within the period from 1868 to 1917 occurred in complicated historic conditions. On the one hand reactionary antinational policy of the Russian empire restrained cultural development of the nations, in particular, limited the activities of the libraries by putting them into bad position and in every way pretending to open national cultural centers. On the other hand, effort of leading Russian intelligence promoted the development of library network and accessibility of the libraries for workers. Thereby, work, done by leading Russian intelligence on formation of library deal, however allowed to creation the base and gain experience on the base, which turned into a successful cultural construction though it changed cultural level of the scolded nationalities a little.

\section{REFERENCES}

1. Avsharova, M. P. (1960), Russian periodic publication in Turkestan (1879-1917). Bibliographic pointers, State Publishing House UzSSR, Tashkent (in Russ.). - 198 p.

2. Bartold, V. V. (1927), Istoriya kul'turnoy zhizni Turkestana [The history of cultural life in Turkestan], Leningrad (in Russ.). - $256 \mathrm{p}$.

3. Geyer, I. I. (ed.), (1981), Collection of material for the statistics of Sirdarya Region, S.I. Lakhtin, Tashkent (in Russ.). -446 p.

4. Dobrosmislov, A. I. (1912), Tashkent v proshlom i nastoyashchem. Istoricheskiy ocherk [Tashkent in the 
past and present. Historical essay], Tashkent (in Russ.). - 520 p.

5. Hajiahmetov, A. (1965), "Russian literature in pre-Revolutionary Turkestan", Zvezda Vostoka, p. 215 (in Russ.).

6. Hamrayeva, T. R. (2011), Creation of statistical service in Turkestan and its activity (the end of 19th - the beginning of 2oth centuries) (on the example of Fergana province): Thesis of the dissertation of PhD in history, Tashkent, (in Russ.). - 28 p.

7. Kari Niyazov, T. N. (1955), Essays on the history of culture in Soviet Uzbekistan, Academy of Sciences of the USSR, Moscow (in Russ.). -560 p.

8. Kasimov, A. G. (1959) Collection of Turkestan. The Soviet Bibliography, 5, 70-77 (in Russ.). pp 70-77.

9. Kasimova, A. G. (1981), Istoriya bibliotechnogo dela $\mathrm{v}$ Uzbekistane [History of Librarianship in Uzbekistan], Ukituvchi, Tashkent (in Russ.). 169 p.

10. Kudinova, O. M. (1976), "Some questions of development of the Russian official publication in provinces and 'Turkestan bordereau"' Voprosy zhurnalistiki [Question of journalism], Publishing house of Tashkent University, Tashkent, p. 132. (in Russ.).

11. Lunin, B. V. (1962), Nauchnyye obshchestva Turkestana i ikh progressivnaya deyatel'nost' (konets XIX - nachalo XX veka) [Scientific societies of Turkestan and their progressive activities (late XIX - early XX century)], Fan, Tashkent (in Russ.). $344 \mathrm{p}$.
12. Lytkina, E. (1957), Bibliotechnoye delo v Tashkente do $1917 \mathrm{~g}$. [Librarianship in Tashkent until 1917], Uzdavnashr, Tashkent (in Russ.). 48 p.

13. Sergeev, B. S. (1935), "The most valuable eastern manuscripts of the State Public Library of the UzSSR", Proceedings of the State Public Library of the UzSSR, State Publishing House of the UzSSR, Tashkent, Vol. 1, p 38. (in Russ.).

14. Shodmonova, S. (2007), "From the history of the official publications in Turkestan. (On example of newspaper 'Turkestan bordereau')", Uzbekiston tarikhi [History of Uzbekistan], 4, p 76. (in Russ.).

15. Tursunov, R. (2007), Problems of social-economic life in Turkestan in the national periodic publications at the beginning of the twentieth century. Uzbekiston tarikhi [History of Uzbekistan], 1, pp 76. (in Russ.).

16. Virskiy, M. (comp.) (1889) Commercial address of Turkestan, Samarkand (in Russ.). p. 129.

17. Vyatkin V.L. Samarkand and its environs in the past according to the description of Sultan Babur Mirza. Translation from Babur-name // Statistical Committee of the Samarkand region. - Samarkand, 1896. - p. 30. 